\title{
Metabolic Syndrome as a Factor Affecting on Intima-Media Thickness in Patients with Rheumatoid Arthritis
}

\author{
Lyudmila Gennadievna Turgunova ${ }^{1} \mathbb{D}$, AnnaAndreevna Shalygina $^{2 \star}$, Lyazat Kataevna Ibrayeva $^{2}$, AnarAkylbecovna Turmuhambetova $^{3}$ \\ ${ }^{1}$ Department of Internal Medicine, Karaganda Medical University, Karaganda, Kazakhstan; ${ }^{2}$ Karaganda Medical University, \\ Karaganda, Kazakhstan; ${ }^{3}$ Department of Strategic Development, Karaganda Medical University, Research and International \\ Collaboration, Karaganda, Kazakhstan
}

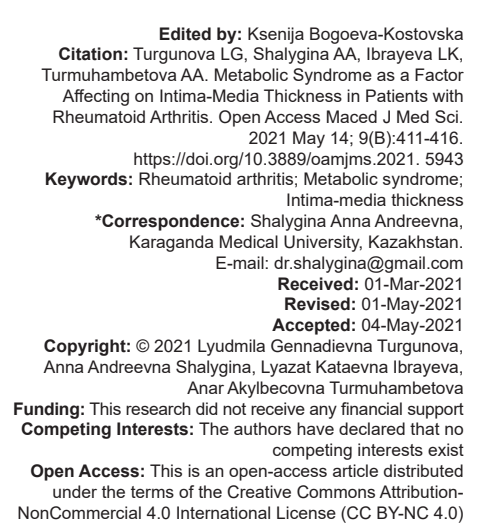

Abstract

AIM: The aim of the study was to assess the association of the thickness of the intima-media complex with metabolic syndrome (MetS) and the degree of disease activity in patients with rheumatoid arthritis (RA).

MATERIALS AND METHODS: The study included 101 patients with RA. All patients underwent a biochemical examination, the presence of MetS was determined, and the carotid thickness of the intima-media was determined. Statistical processing was performed using SPSS for Windows, version 18.0.

RESULTS: Among 101 patients with RA, 41 (40.5\%) had MetS. The frequency of detecting an increased value of the intima-media complex thickness was significantly higher in the group with MetS $(n=31[75.6 \%])$ than in the group without MetS $(n=21[35.0 \%] p \leq 0.0001)$. In the group of patients with MetS, the median carotid intima-media thickness (CIMT) was $1.2 \mathrm{~mm}$, while this indicator in the group without MetS was $0.78 \mathrm{~mm}(\mathrm{U}=727, \mathrm{p}=0.001)$. In the regression model, MetS $(B=1.05 ; p=0.027)$ and DAS28-ESR $(B=0.506 ; p=0.021)$ were influenced by CIMT. CONCLUSIONS: The results of our study show the effect of MetS and RA activity on the increase of intima-media thickness.

\section{Introduction}

Rheumatoid arthritis (RA) is a systemic immune-inflammatory disease characterized by early disablement of patients and increased cardiovascular risk [1], [2]. Previous studies have shown that the mortality rate in patients with RA is 1.5 times higher than in the general population [3], [4]. The high prevalence of cardiovascular diseases among patients with RA determines the search for the causes of this fact. The researchers attribute the increased risk of cardiovascular disease in rheumatoid patients to the persistence of chronic systemic inflammation, the higher prevalence of traditional cardiovascular risk factors, and the negative effects of drugs used to treat RA on the cardiovascular system. However, all these factors cannot fully explain the more rapid development and progression of atherosclerosis as the main pathogenetic mechanism of cardiovascular diseases in patients with RA [5], [6].

Metabolic syndrome (MetS), which includes an increase of waist circumference (WC), a decrease in high-density lipoprotein (HDL) cholesterol, an increase in triglycerides, arterial hypertension, and hyperglycemia, is associated with the development of cardiovascular diseases in the general population [7], [8]. In a meta-analysis, Zhang et al. have been shown that in patients with RA, the prevalence of MetS is higher than in patients without RA [9]. It was also previously shown that the presence of MetS in patients with RA is associated with higher disease activity and less effective therapy [10], [11].

The intima-media thickness (IMT) is considered as a surrogate marker of cardiovascular risk [12]. Despite the fact that modern methods of IMT imaging, such as carotid magnetic resonance imaging, are currently available, the use of ultrasound to determine carotid IMT remains an actual method in patients with RA [13], [14].

Previously, it was shown that patients with RA have higher IMT than in the control group [15]. There is also evidence of higher IMT scores in patients with MetS [16], [17], [18]. It can be assumed that the simultaneous presence of both MetS and RA in the patient will lead to a faster progression of atherosclerotic artery damage. However, there are not enough studies to determine IMT in patients with comorbidity of RA and MetS, and the results of these studies are different [19], [20]. Thus, the aim of our study is to determine the carotid intima-media thickness 
(CIMT) in patients with RA and MetS and to determine the relationship of IMT with RA activity indicators.

\section{Materials and Methods}

\section{Patients}

The study included 101 patients with RA. The diagnosis of RA was established according to the 2010 ACR/European League Against Rheumatism/American College of Rheumatology 1987 criteria for RA [21], [22]. The exclusion criteria were age are over 50 years old, history of cardiovascular disease such as myocardial infarction, cerebrovascular damage, obliterating atherosclerosis, coronary stenting, and coronary artery bypass surgery. Researchers obtained a patient history and performed a physical examination. The patients were recruited at Karaganda Medical University Clinic. All study participants signed informed consent before any procedures were started.

\section{MetS}

The MetS was established according to IDF Consensus Worldwide Definition of the MetS (IDF, 2009) [23]. It included abdominal obesity (defined as WC $\geq 94 \mathrm{~cm}$ in Europid males and $\geq 80 \mathrm{~cm}$ in females) plus any two of the following four factors: Triglycerides raised more than $150 \mathrm{mg} / \mathrm{dl}(1.7 \mathrm{mmol} / \mathrm{l})$ or specific treatment for this lipid abnormality; HDL cholesterol reduced $<40 \mathrm{mg} / \mathrm{dL}(1.03 \mathrm{mmol} / \mathrm{L})$ in males and $<50 \mathrm{mg} / \mathrm{dL}(1.29 \mathrm{mmol} / \mathrm{L})$ in females or specific treatment for this lipid abnormality; raised systolic $\geq 130$ or diastolic blood pressure $\geq 85 \mathrm{mmHg}$ or treatment of previously diagnosed hypertension; fasting plasma glucose $\geq 100 \mathrm{mg} / \mathrm{dL}$ (5.6 mmol/L), or previously diagnosed type 2 diabetes mellitus.

\section{Laboratory diagnostics}

The glucose level was measured using the Accu-Chek Active Blood Glucose Meter in capillary blood. All blood samples were collected after $12 \mathrm{~h}$ fasting period. Total cholesterol and triglycerides and low-density lipoproteins (LDL) were measured by an enzymatic colorimetric method with selective protection without sedimentation. LDL cholesterol was calculated using the Friedewald formula [24]. The erythrocyte sedimentation rate was established by the Panchenkov method.

\section{Intima media thickness}

The specially trained healthcare professional provided an ultrasound examination of the extracranial part of the carotid artery using EPIC 7 Ultrasound (Philips Ultrasound, 2018, USA). The study was conducted at the patient's back position. The ultrasound images were received using B-mode ultrasound at the distal $1 \mathrm{~cm}$ of the far wall of each common carotid artery [25]. The measurements were taken twice on each side. The final result was established as an arithmetic mean of two measurements on each side. The CIMT exceeded 0.87 $\mathrm{mm}$ was chosen as cut-off point for IMT abnormality according to the literature sources [26], [27], [28].

\section{RA disease activity}

RA disease activity was estimated using the Disease Activity Score with 28 joints counted and the erythrocyte sedimentation rate (DAS28-ESR) [29], [30].

\section{Statistical processing}

Statistical Package for the Social Sciences (SPSS for Windows, ver. 18.0, SPSS Inc., Chicago, Illinois, USA) was used to calculate statistical parameters. Continuous variables were tested for normal distribution using the Kolmogorov-Smirnov test. All the variables in the present study were abnormally distributed, thus, the data were present as the median and interquartile range. Categorical variables were present as numbers and percentages. Mann-Whitney $U$ test was used to provide inter-group comparison. Spearman's rank correlation coefficient was used to establish correlations ( $r s$ ). The results were significant at $p \leq 0.05$. The binary logistic regression model was used to determine the probability of such independent variables as MetS, age, gender, smoking status, systolic blood pressure (SBP), WC, body mass index, C-reactive protein (CRP), total cholesterol, age of RA, and (DAS28-ESR) to predict IMT. The adjusted odds ratios (OR) with corresponding 95\% confidence interval (95\% Cl) were calculated.

\section{Results}

The baseline characteristics of patients with RA and MetS and without it are present in Table 1.

There were no differences between groups by age, gender, number of smoking, and alcohol-using people. The number of people with sufficient physical activity was higher in the RA group; however, there was no statistical significance found between variables. The WC and body mass index were increased in both the $\mathrm{RA}+$ MetS group and RA group, which indicates the high prevalence of abdominal obesity among study participants. The presents of MetS contributed to the significant differences among studied groups by arterial 
blood pressure $(p<0.0001)$, non-fasting glucose $(p<0.0001)$, and triglycerides $(p=0.004)$.

Table 1: Patients baseline characteristics

\begin{tabular}{|c|c|c|c|}
\hline Parameter & RA+ MetS $(n=41)$ & $\mathrm{RA}(\mathrm{n}=60)$ & $\mathrm{p}$ \\
\hline $\begin{array}{l}\text { Age, years, } \mathrm{Me}\left(\mathrm{Q}_{25}-\mathrm{Q}_{75}\right) \\
\text { Gender n. \% }\end{array}$ & $57.0(52.0-60.0)$ & $53.5(47.2-59.0)$ & 0.062 \\
\hline Female & $22(78)$ & $48(80)$ & 0.813 \\
\hline Male & $9(32)$ & $12(20)$ & \\
\hline Current smoker, n (\%) & $6(14.6)$ & $6(10)$ & 0.482 \\
\hline Alcohol use, $\mathrm{n}(\%)$ & $20(48.8)$ & $30(50)$ & 0.905 \\
\hline Sufficient physical activity, n (\%) & $20(48.8)$ & $37(61.7)$ & 0.193 \\
\hline $\begin{array}{l}\text { Body mass index }\left(\mathrm{kg} / \mathrm{m}^{2}\right), \mathrm{Me} \\
\left(\mathrm{Q}_{25}-\mathrm{Q}_{75}\right)\end{array}$ & $29.8(27.2-32.9)$ & $27.3(22.8-30.8)$ & 0.01 \\
\hline$W C(\mathrm{~cm}), \operatorname{Me}\left(Q_{25}-Q_{75}\right)$ & $100.0(95.0-108.0)$ & $91.5(83.2-99.7)$ & $<0.0001$ \\
\hline $\mathrm{SBP} \mathrm{mm} / \mathrm{Hg}, \operatorname{Me}\left(\mathrm{Q}_{25}-\mathrm{Q}_{75}\right)$ & $140.0(122.0-150.0)$ & $120.0(115.0-130.0)$ & $<0.0001$ \\
\hline $\begin{array}{l}\text { Total cholesterol }(\mathrm{mmol} / \mathrm{L}), \mathrm{Me} \\
\left(\mathrm{Q}_{25}-\mathrm{Q}_{75}\right)\end{array}$ & $5.6(4.8-7.2)$ & $6.2(4.8-7.6)$ & 0.535 \\
\hline $\mathrm{HDL}-\mathrm{C}^{75}(\mathrm{mmol} / \mathrm{L}), \mathrm{Me}\left(\mathrm{Q}_{2}-\mathrm{Q}_{75}\right)$ & $1.3(1.06-2.8)$ & $1.6(1.3-2.3)$ & 0.597 \\
\hline LDL-C (mmol/L), $\mathrm{Me}\left(\mathrm{Q}_{25}-\mathrm{Q}_{75}\right)$ & $3.0(2.4-3.9)$ & $3.2(2.5-4.1)$ & 0.425 \\
\hline Triglycerides $(\mathrm{mmol} / \mathrm{L}), \mathrm{Me}\left(\mathrm{Q}_{25}-\mathrm{Q}_{75}\right)$ & $1.5(0.8-2.2)$ & $1.01(0.6-1.3)$ & 0.004 \\
\hline $\begin{array}{l}\text { Non-fasting glucose }(\mathrm{mmol} / \mathrm{l}), \mathrm{Me} \\
\left(\mathrm{Q}_{25}-\mathrm{Q}_{75}\right)\end{array}$ & $5.7(5.2-6.1)$ & $5.2(5.0-5.6)$ & $<0.0001$ \\
\hline $\begin{array}{l}\text { Erythrocyte sedimentation rate } \\
(\mathrm{mm} / \mathrm{h}), \mathrm{Me}\left(Q_{25}-Q_{75}\right)\end{array}$ & $23.5(9.0-30.0)$ & $16.0(10.0-28.5)$ & 0.465 \\
\hline $\operatorname{CRP}(\mathrm{mg} / \mathrm{l}), \mathrm{Me}\left(\mathrm{Q}_{25}-\mathrm{Q}_{75}\right)$ & $5.0(5.0-11.0)$ & $5.0(5.0-10.0)$ & 0.827 \\
\hline DAS28-ESR, $\mathrm{Me}\left(\mathrm{Q}_{25}-\mathrm{Q}_{75}\right)$ & $4.9(3.8-5.4)$ & $4.3(3.6-5.0)$ & 0.106 \\
\hline$\leq 2.6, \mathrm{n}(\%)$ & $3(7.3)$ & $12(20)$ & \\
\hline $2.6-3.2, \mathrm{n}(\%)$ & $20(48.8)$ & $33(55)$ & \\
\hline$\geq 3.2, \mathrm{n}(\%)$ & $18(43.9)$ & $15(25)$ & \\
\hline $\begin{array}{l}\text { RA disease duration (years), } \mathrm{Me} \\
\left(\mathrm{Q}_{25}-\mathrm{Q}_{75}\right)\end{array}$ & $10.0(5.0-23.0)$ & $6.0(5.0-11.0)$ & 0.056 \\
\hline Current corticosteroids use, $\mathrm{n}(\%)$ & $18(43.9)$ & $30(50)$ & 0.549 \\
\hline Current DMARDs use, $n(\%)$ & $28(68.3)$ & $46(76.7)$ & 0.353 \\
\hline
\end{tabular}

The median of RA duration was higher in the RA+ MetS group Me = $10.0(\mathrm{Q} 25=5.0 ; \mathrm{Q} 75=$ 23.0) years than in RA group $M e=6.0(Q 25=5.0$; $\mathrm{Q} 75=11.0$ ) years, however, the median age did not show significant differences. About half of the study participants took corticosteroids to treat RA. The number of disease-modifying antirheumatic drug users was $68.3 \%$ in the RA+ MetS group and $76.7 \%$ in the RA group. The DAS28-ESR level shows no differences between studied groups, but it is worth mentioning that high RA disease activity (DAS28-ESR $\geq 3.2$ ) was 1.75 folds bigger in RA+ MetS than in the RA group.

The results of our study show that increased IMT was significantly higher in the RA+MetS group $(n=31[75.6 \%])$, compared with the RA group $(n=21$ [35.0\%] $p \leq 0.0001)$.

Figure 1 demonstrated the parameters of quantitative CIMT in RA+ MetS and RA patients. According to the figure median CIMT in RA+ MetS group accounted for $1.2 \mathrm{~mm}$, whereas CIMT in RA group was $0.78 \mathrm{~mm}(U=727, \mathrm{p}=0.001)$.

The results of correlation analysis are demonstrated in Table 2.

The initial characteristics of study participants in the RA group did not include division of study participants by MetS presents or absence. The CIMT thickening has weak positive correlation with age $\left(r_{s}=0.207\right)$, smoking status $\left(r_{s}=0.248\right)$, body mass index $\left(r_{s}=0.377\right)$, WC $\left(r_{s}=0.44\right)$, SBP $\left(r_{s}=0.375\right)$, and DAS28 $\left(r_{s}=0.277\right)$ disease activity index. The weak positive correlation was found between MetS and CIMT thickening $\left(r_{s}=0.288, p=0.003\right)$. In our study, no correlation was found between CIMT thickening

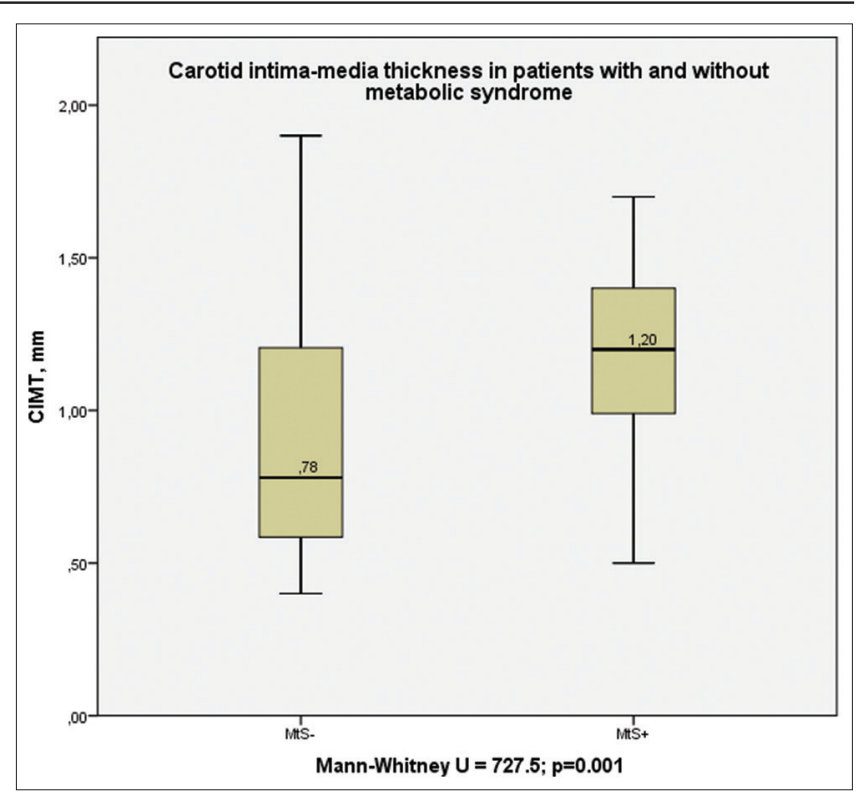

Figure 1: Carotid intima-media thickness in patients with rheumatoid arthritis with and without metabolic syndrome

and traditional cardiovascular risk factors, as well as RA-related parameters in patients with RA+MetS. There were correlations between subclinical atherosclerosis parameters and body mass index (BMI) $\left(r_{s}=0.361\right)$, WC $(r=0.427)$, SBP $(r=0.336)$, or RA disease duration $\left(r_{s}=-0.292\right)$ in RA group.

Table 2: Correlation analysis of CIMT thickening factors and baseline respondents' characteristics

\begin{tabular}{|c|c|c|c|c|c|c|}
\hline \multirow[t]{2}{*}{ Parameter } & \multicolumn{2}{|c|}{$\begin{array}{l}\text { Total study group } \\
(\mathrm{n}=101)\end{array}$} & \multicolumn{2}{|c|}{$\begin{array}{l}\text { RA with MetS } \\
(\mathrm{n}=41)\end{array}$} & \multicolumn{2}{|c|}{$\begin{array}{l}\text { RA without } \\
\text { MetS }(n=60)\end{array}$} \\
\hline & rs & $\mathrm{p}$ & rs & $\mathrm{p}$ & rs & $\mathrm{p}$ \\
\hline Age & 0.207 & 0.038 & 0.031 & 0.846 & 0.23 & 0.06 \\
\hline Gender & -0.135 & 0.177 & -0.164 & 0.304 & -0.117 & 0.374 \\
\hline Current smoker & -0.248 & 0.013 & -0.235 & 0.139 & -0.245 & 0.059 \\
\hline Sufficient physical activity & 0.111 & 0.287 & 0.088 & 0.599 & 0.065 & 0.632 \\
\hline Body mass index & 0.377 & 0.0001 & 0.228 & 0.152 & 0.361 & 0.005 \\
\hline WC & 0.44 & 0.0001 & 0.267 & 0.091 & 0.427 & 0.001 \\
\hline $\mathrm{SBP} \mathrm{mm} / \mathrm{Hg}$ & 0.375 & 0.0001 & 0.247 & 0.119 & 0.336 & 0.009 \\
\hline Total cholesterol & -0.150 & 0.136 & -0.158 & 0.323 & -0.134 & 0.312 \\
\hline HDL-C & -0.071 & 0.479 & -0.187 & 0.241 & 0.022 & 0.866 \\
\hline LDL-C & -0.158 & 0.117 & -0.15 & 0.355 & -0.143 & 0.277 \\
\hline Triglycerides & 0.182 & 0.069 & 0.048 & 0.766 & 0.147 & 0.264 \\
\hline Non-fasting glucose & 0.016 & 0.877 & -0.063 & 0.697 & -0.063 & 0.631 \\
\hline Erythrocyte sedimentation rate & 0.17 & 0.115 & 0.13 & 0.463 & 0.154 & 0.27 \\
\hline CRP & 0.19 & 0.057 & 0.193 & 0.226 & 0.214 & 0.1 \\
\hline DAS28-ESR & 0.277 & 0.005 & 0.266 & 0.102 & 0.22 & 0.091 \\
\hline RA disease duration & 0.122 & 0.223 & -0.036 & 0.823 & -0.292 & 0.024 \\
\hline Current corticosteroids use & -0.002 & 0.987 & 0.045 & 0.782 & 0.0 & 1.0 \\
\hline Current DMARDs use & 0.126 & 0.21 & 0.101 & 0.529 & 0.2 & 0.125 \\
\hline MetS & 0.288 & 0.003 & & & & \\
\hline
\end{tabular}

CIMT: Carotid intima-media thickness, MetS: Metabolic syndrome, WC: Waist circumference,

HDL: High-density lipoprotein, LDL: Low-density lipoproteins, SBP: Systolic blood pressure,

CRP: C-reactive protein.

The univariate logistic regression model was created to establish the probable impact of MetS on CIMT thickening in patients with RA. MetS, age, gender, smoking status, WC, CRP, total cholesterol, RA disease duration, and DAS28-ESR were chosen as covariates. The covariates with $p \leq 0.05$ were elected for further Multivariate Logistic Regression. The analysis established MetS as an independent predictor of CIMT thickening in RA patients (Table 3, Model 1).

The adjusted regression model established such statistically significant confounders as age, gender, and MetS (Table 3, Model 2). The third regression model included the DAS28-ESR was added 
to model 2. MetS and DAS28-ESR show a significant impact on CIMT thickness probability (Table 3, Model 3) for rheumatoid patients.

Table 3: Models of logistic regression for RA patients and CIMT as a dependent variable

\begin{tabular}{|c|c|c|c|c|c|c|c|}
\hline \multirow{2}{*}{$\begin{array}{l}\text { Model and } \\
\text { depend variable }\end{array}$} & \multirow[t]{2}{*}{ B } & \multirow[t]{2}{*}{ Mean square error } & \multirow[t]{2}{*}{ Wald } & \multirow{2}{*}{$\mathrm{p}$-value } & \multirow{2}{*}{$\operatorname{Exp}(B)$} & \multicolumn{2}{|l|}{$95 \% \mathrm{Cl}$} \\
\hline & & & & & & Lower & Upper \\
\hline \\
\hline MetS & 1.265 & 0.446 & 8.032 & 0.005 & 0.282 & 0.118 & 0.677 \\
\hline \multicolumn{8}{|l|}{ Model 2} \\
\hline MetS & 1.161 & 0.458 & 6.429 & 0.011 & 0.313 & 0.128 & 0.768 \\
\hline Age & 0.642 & 0.032 & 2.095 & 0.148 & 1.048 & 0.984 & 1.116 \\
\hline Gender & -1.578 & 0.559 & 1.319 & 0.251 & 1.9 & 0.636 & 5.679 \\
\hline \multicolumn{8}{|l|}{ Model 3} \\
\hline MetS & 1.05 & 0.476 & 4.869 & 0.027 & 0.35 & 0.138 & 0.889 \\
\hline Age & 0.028 & 0.034 & 0.086 & 0.408 & 1.028 & 0.963 & 1.098 \\
\hline Gender & 0.833 & 0.586 & 2.023 & 0.155 & 2.3 & 0.73 & 7.249 \\
\hline DAS28-ESR & 0.506 & 0.219 & 5.364 & 0.021 & 1.659 & 1.081 & 2.546 \\
\hline
\end{tabular}

Further analysis using logistic regression was provided separately for MetS+RA and RA groups. The univariate logistic model included age, gender, smoking status, SBP, WC, BMI, CRP, total cholesterol, RA disease duration, treatment regimen, and DAS28-ESR. The covariates with $p \leq 0.05$ were elected for further Multivariate Logistic Regression. The CIMT thickness was influenced by DAS28-ESR disease activity score (Table 4, Model for RA with MetS) in RA patients with MetS.

Table 4: Models of logistic regression for patients with RA with and without MetS and CIMT as a dependent variable

\begin{tabular}{|c|c|c|c|c|c|c|c|}
\hline \multirow{2}{*}{$\begin{array}{l}\text { Model and } \\
\text { depend variable }\end{array}$} & \multirow[t]{2}{*}{ B } & \multirow{2}{*}{$\begin{array}{l}\text { Mean square } \\
\text { error }\end{array}$} & \multirow[t]{2}{*}{ Wald } & \multirow[t]{2}{*}{$P$ value } & \multirow[t]{2}{*}{$\operatorname{Exp}(\mathrm{B})$} & \multicolumn{2}{|l|}{$95 \% \mathrm{Cl}$} \\
\hline & & & & & & Lower & Upper \\
\hline Model for RA with & 0.768 & 0.376 & 4.186 & 0.041 & 2.156 & 1.033 & 4.503 \\
\hline MtS DAS28-ESR & & & & & & & \\
\hline $\begin{array}{l}\text { Model for RA } \\
\text { without MtS BMI }\end{array}$ & 0.14 & 0.05 & 6.66 & 0.01 & 1.15 & 1.03 & 1.27 \\
\hline
\end{tabular}

There was no significant impact on CIMT thickness found when DAS28-ESR was used as an independent variable of regression analysis in RA patients without MetS (Table 4). Taking into account the early revealed association, BMI, SBP, and RA disease duration were chosen as confounders for the adjusted regression model. The BMI was established as a significant confounder of subclinical atherosclerosis risk in RA patients (Table 4, Model for RA without MetS).

\section{Discussion}

The literature, particularly the results of meta-analysis, demonstrated high CIMT in RA patients; however, the studies have not analyzed the prevalence of MetS in those patients [31], [13]. The CIMT in our study was higher in patients with MetS in combination with RA than in RA. Furthermore, we built a few logistic regression models aimed to identify factors that predispose to CIMT thickening in patients with RA and MetS and RA alone. We identified that the presents of MetS in RA patients increased CIMT thickening risk on $72 \%$ according to the adjusted regression model (confounders age and gender). The third regression model for RA patients showed the joint impact of MetS and rheumatoid disease activity score on CIMT thickening. The impact of disease activity score on CIMT had not lost its importance for MetS and RA patients proving the significance of inflammation for subclinical atherosclerosis. It was interesting to see that the BMI as confounder shows an impact on subclinical atherosclerosis in RA alone patients. This fact allows suggesting the increased $\mathrm{BMI}$ as a possible factor of cardiovascular risk in RA patients before MetS development; however, further research needed.

The results of our study are correlated with the prospective study of Burggraaf et al. where researchers demonstrated that baseline CIMT of RA patients with MetS had was higher compared to those without MetS (0.607 [0.107] vs. 0.556 [0.103] mm; $p=0.001)$ [20]. It is important to notify that the influence of rheumatoid disease activity on CIMT was demonstrated in several studies of RA alone patients [18], [2], [32]. The study of Uslu et al. reported the positive correlation of CIMT and disease activity score of 28 joints $(p=0.002)$ in 52 patients with RA [18]. The population study of MaraditKremers et al. demonstrated higher swollen joint counts and higher average CRP were associated with carotid intima medial plaques in RA patients [19]. The authors of another study did not find any correlation between CIMT and DAS28 among RA patients [33]. Despite conflicting reports from the literature, the significance of systemic inflammation is increasingly becoming the main agent for triggering and developing atherosclerosis. According to the latest data, RA is considered not only as an immunoinflammatory disease but also as a model of atherosclerosis fasten progress [34]. The systemic inflammation is a general pathogenetic chain of RA and MetS that realizes their proatherogenic effect through endothelial dysfunction, oxidative stress, macrophage accumulation, toll-like receptor signaling, NLPR-3 formation, and subsequent pro-inflammatory cytokine production, such as TNFa, IL-1 $\beta, \mathrm{IL}-6$, and TNF-like cytokine 1A [35]. Furthermore, inflammation influences several traditional cardiovascular risk factors as dyslipidemia, obesity, and insulin resistance, which are the MetS components simultaneously [36]. The detailed RA and MetS pathogenetic mechanisms and their concomitant impact on atherosclerosis required future study to improve understanding of the process and search for reasonable preventive measures.

Our research team did not reveal any correlation between the type of RA treatment implemented among study participants and CIMT. However, several studies report the opposite trend. In the recent study, authors show that methotrexate use was connected with a lower IMT [31]. The study of Kim et al. revealed lower CIMT in RA with methotrexate as compared with RA without methotrexate $(0.644 \pm 0.136 \mathrm{~mm}, 0.767 \pm 0.233 \mathrm{~mm}$, respectively, $p<0.05)$. Furthermore, the effects of 
methotrexate on CIMT were correlated with its dosage $(\beta=-0.029, p<0.01)[36]$. The absence of correlation between treatment and CIMT was probably connected with the insufficient anti-inflammatory effect of drugs and with a high percentage of corticosteroids in the treatment regimen of patients.

There were several limitations in our study because of a relatively small number of patients and observational study design. Further prospective cohort studies are needed for RA and MetS continuum evaluation.

Thus, the results of our study show more frequent CIMT thickening in RA patients with MetS compared with RA alone patients. Patients with RA and MetS demonstrate the impact of disease activity score on subclinical atherosclerosis. In RA alone patients' study revealed the impact of BMI on CIMT thickening prevalence. We can conclude that the disease management of rheumatoid patients should include activities aimed at early diagnostics of MetS because of its association with increased cardiovascular risk in this patient. In turn, the disease activity score in patients with RA and MetS should be carefully monitored due to the fact that sustainable chronic inflammation leads to atherosclerosis progression and adverse cardiovascular events. Nowadays, many practical questions on MetS management in RA patients rest unsolved. Improving the mechanisms for diagnosing MetS in patients with RA, finding tools for an adequate assessment of cardiovascular risk in patients with $\mathrm{RA}$, and developing and implementing effective lifestyle modification measures may be the key to reducing cardiovascular pathology in patients with RA and increasing their life expectancy and quality.

\section{References}

1. van Halm VP, Peters MJ, Voskuyl AE, Boers M, Lems WF, Visser $\mathrm{M}$, et al. Rheumatoid arthritis versus diabetes as a risk factor for cardiovascular disease: A cross-sectional study, the CARRE investigation. Ann Rheum Dis. 2009;68(9):1395-400. https://doi.org/10.1136/ard.2008.094151

PMid: 18697775

2. del Rincón I, Polak JF, O'Leary DH, Battafarano DF, Erikson JM, Restrepo JF, et al. Systemic inflammation and cardiovascular risk factors predict rapid progression of atherosclerosis in rheumatoid arthritis. Ann Rheum Dis. 2015;74(6):1118-23. https://doi.org/10.1136/annrheumdis-2013-205058 PMid:24845391

3. Aviña-Zubieta JA, Choi HK, Sadatsafavi M, Etminan M, Esdaile JM, Lacaille D. Risk of cardiovascular mortality in patients with rheumatoid arthritis: A meta-analysis of observational studies. Arthritis Rheum. 2008;59(12):1690-7. https://doi.org/10.1002/art.24092

PMid: 19035419

4. Fischer LM, Schlienger RG, Matter C, Jick H, Meier CR. Effect of rheumatoid arthritis or systemic lupus erythematosus on the risk of first-time acute myocardial infarction. Am
J Cardiol. 2004;93(2):198-200. https://doi.org/10.1016/j. amjcard.2003.09.037

PMid:14715346

5. Reiss AB, Silverman A, Khalfan M, Vernice NA, Kasselman LJ, Carsons SE, et al. Accelerated atherosclerosis in rheumatoid arthritis: Mechanisms and treatment. Curr Pharm Des. 2019;25(9):969-86. https://doi.org/10.2174/1381612825666190 430113212

PMid:31208307

6. Arida A, Protogerou AD, Kitas GD, Sfikakis PP. Systemic inflammatory response and atherosclerosis: The paradigm of chronic inflammatory rheumatic diseases. Int J Mol Sci. 2018;19(7):1890. https://doi.org/10.3390/ijms19071890 PMid:29954107

7. Jung JM, Kwon DY, Han C, Park MH. Metabolic syndrome and early carotid atherosclerosis in the elderly. J Atheroscler Thromb. 2014;21(5):435-44.

PMid:24477027

8. Gami AS, Witt BJ, Howard DE, Erwin PJ, Gami LA, Somers VK, et al. Metabolic syndrome and risk of incident cardiovascular events and death: A systematic review and meta-analysis of longitudinal studies. J Am Coll Cardiol. 2007;49(4):403-14. https://doi.org/10.1016/j.jacc.2006.09.032 PMid:17258085

9. Zhang J, Fu L, Shi J, Chen X, LiY, Ma B, et al. The risk of metabolic syndrome in patients with rheumatoid arthritis: A meta-analysis of observational studies. PLoS One. 2013;8(10):e78151. https:// doi.org/10.1371/journal.pone.0078151

PMid:24205134

10. Rostom S, Mengat M, Lahlou R, Hari A, Bahiri R, HajjajHassouni N. Metabolic syndrome in rheumatoid arthritis: Case control study. BMC Musculoskelet Disord. 2013;14:147. https:// doi.org/10.1186/1471-2474-14-147

PMid:23621997

11. Chung CP, Oeser A, Solus JF, Avalos I, Gebretsadik T, Shintani $A$, et al. Prevalence of the metabolic syndrome is increased in rheumatoid arthritis and is associated with coronary atherosclerosis. Atherosclerosis. 2008;196(2):756-63. https:// doi.org/10.1016/j.atherosclerosis.2007.01.004 PMid:17266963

12. Lorenz MW, Markus HS, Bots ML, Rosvall M, Sitzer M. Prediction of clinical cardiovascular events with carotid intima-media thickness: A systematic review and meta-analysis. Circulation. 2007;115(4):45967. https://doi.org/10.1161/circulationaha.106.628875

PMid:17242284

13. van Sijl AM, Peters MJ, Knol DK, de Vet HC, GonzalezGay MA, Smulders YM, et al. Carotid intima media thickness in rheumatoid arthritis as compared to control subjects: A metaanalysis. Semin Arthritis Rheum. 2011;40(5):389-97. https://doi. org/10.1016/j.semarthrit.2010.06.006 PMid:20889191

14. Wah-Suarez MI, Galarza-Delgado DA, Azpiri-Lopez JR, ColungaPedraza IJ, Cardenas-de la Garza JA, Vera-Pineda R, et al. The best cardiovascular risk calculator to predict carotid plaques in rheumatoid arthritis patients. Clin Rheumatol. 2018;37(9):237380. https://doi.org/10.1007/s10067-018-4181-4 PMid:29967925

15. Ambrosino P, Lupoli R, Di Minno A, Tasso M, Peluso R, Di Minno MN. Subclinical atherosclerosis in patients with rheumatoid arthritis. A meta-analysis of literature studies. Thromb Haemost. 2015;113(5):916-30. https://doi.org/10.1160/th14-11-0921 PMid:25716931

16. Zhou PA, Zhang $\mathrm{CH}$, Chen YR, Li D, Song DY, Liu HM, et al. Association between metabolic syndrome and carotid atherosclerosis: A cross-sectional study in Northern China. 
Biomed Environ Sci. 2019;32(12):914-21.

PMid:31918796

17. Cuspidi C, Sala C, Provenzano F, Tadic M, Gherbesi E, Grassi G, et al. Metabolic syndrome and subclinical carotid damage: A meta-analysis from population-based studies. J Hypertens. 2018;36(1):23-30. https://doi.org/10.1097/ hjh.0000000000001575 PMid:29035943

18. Uslu AU, Kucuk A, Balta S, Ozturk C, Arslan S, Tekin L, et al. The relation between ischemia modified albumin levels and carotid intima media thickness in patients with rheumatoid arthritis. Int J Rheum Dis. 2019;22(1):32-7. https://doi. org/10.1111/1756-185x.12851 PMid:27028097

19. Maradit-Kremers H, Nicola PJ, Crowson CS, Ballman KV, Gabriel SE. Cardiovascular death in rheumatoid arthritis: A population-based study. Arthritis Rheum. 2005;52(3):722-32. https://doi.org/10.1002/art.20878

PMid:15751097

20. Burggraaf B, van Breukelen-van der Stoep DF, de Vries MA Klop B, van Zeben J, van de Geijn GM, et al. Progression of subclinical atherosclerosis in subjects with rheumatoid arthritis and the metabolic syndrome. Atherosclerosis. 2018;271:84-91. https://doi.org/10.1016/j.atherosclerosis.2018.02.019 PMid:29482038

21. Aletaha D, Neogi T, Silman AJ, Funovits J, Felson DT, Bingham CO $3^{\text {rd }}$, et al. 2010 Rheumatoid arthritis classification criteria: An American college of rheumatology/European league against rheumatism collaborative initiative. Arthritis Rheum. 2010;62(9):2569-81. https://doi.org/10.1002/art.27583 PMid:20872595

22. Arnett FC, Edworthy SM, Bloch DA, McShane DJ, Fries JF, Cooper NS, et al. The American rheumatism association 1987 revised criteria for the classification of rheumatoid arthritis. Arthritis Rheum. 1988;31(3):315-24. https://doi.org/10.1002/ art. 1780310302

PMid:3358796

23. Alberti KG, Zimmet P, Shaw J. Metabolic syndrome--a new worldwide definition. A consensus statement from the international diabetes federation. Diabet Med. 2006;23(5):469-80. https://doi. org/10.1111/j.1464-5491.2006.01858.x PMid:16681555

24. Friedewald WT, Levy RI, Fredrickson DS. Estimation of the concentration of low-density lipoprotein cholesterol in plasma, without use of the preparative ultracentrifuge. Clin Chem. 1972;18(6):499-502. https://doi.org/10.1093/clinchem/18.6.499 PMid:4337382

25. Stein JH, Korcarz CE, Hurst RT, Lonn E, Kendall CB, Mohler ER, et al. Use of carotid ultrasound to identify subclinical vascular disease and evaluate cardiovascular disease risk: A consensus statement from the American Society of Echocardiography Carotid Intima-Media Thickness Task Force. Endorsed by the society for vascular medicine. J Am Soc Echocardiogr. 2008;21(2):93-111; quiz 189-90. https://doi.org/10.1016/j.echo.2007.11.011 PMid:18261694

26. Bots ML, Hoes AW, Koudstaal PJ, Hofman A, Grobbee DE. Common carotid intima-media thickness and risk of stroke and myocardial infarction: The Rotterdam study. Circulation. 1997;96(5):1432-7. https://doi.org/10.1161/01.cir.96.5.1432 PMid:9315528

27. O'Leary DH, Polak JF, Kronmal RA, Manolio TA, Burke GL, Wolfson SK Jr. Carotid-artery intima and media thickness as a risk factor for myocardial infarction and stroke in older adults. Cardiovascular health study collaborative research group. N Engl J Med. 1999;340(1):14-22. https://doi.org/10.1056/ nejm199901073400103 PMid:9878640

28. del Sol Al, Bots ML, Grobbee DE, Hofman A, Witteman JC. Carotid intima-media thickness at different sites: Relation to incident myocardial infarction; The Rotterdam study. Eur Heart J. 2002;23(12):934-40. https://doi.org/10.1053/euhj.2001.2965 PMid:12069447.

29. Prevoo ML, van't Hof MA, Kuper HH, van Leeuwen MA, van de Putte LB, van Riel PL. Modified disease activity scores that include twenty-eight-joint counts. Development and validation in a prospective longitudinal study of patients with rheumatoid arthritis. Arthritis Rheum. 1995;38(1):44-8. https:// doi.org/10.1002/art.1780380107

PMid:7818570

30. Fransen J, Welsing P, Keijzer RD, Riel PV. Disease activity scores using C-reactive protein: CRP may replace ESR in the assessment of RA disease activity. Ann Rheum Dis 2004;62:151.

31. Pinto MRC, Kakehasi AM, Souza AJ, Tavares WC Jr., Rocha MA, Trant CG, et al. Methotrexate use, not interleukin 33, is associated with lower carotid intima-media thickness in patients with rheumatoid arthritis. Adv Rheumatol. 2019;59(1):15. https:// doi.org/10.1186/s42358-019-0060-1 PMid:30944039

32. Targońska-Stepniak B, Drelich-Zbroja A, Majdan M. The relationship between carotid intima-media thickness and the activity of rheumatoid arthritis. J Clin Rheumatol. 2011;17(5):24955. https://doi.org/10.1097/rhu.0b013e3182290dbf PMid:21778898

33. Beyazal MS, Erdoğan T, Devrimsel G, Türkyılmaz AK, Cüre MC, Beyazal M, et al. Relationship of osteoprotegerin to pulse wave velocity and carotid intima-media thickness in rheumatoid arthritis patients. Z Rheumatol. 2016;75(7):723-8. https://doi. org/10.1007/s00393-015-1675-1 PMid:26555551

34. Adawi M, Firas S, Blum A. Rheumatoid arthritis and atherosclerosis. Isr Med Assoc J. 2019;21(7):460-3. PMid:31507121

35. Arida A, Protogerou AD, Konstantonis G, Fragiadaki K, Kitas GD Sfikakis PP. Atherosclerosis is not accelerated in rheumatoid arthritis of low activity or remission, regardless of antirheumatic treatment modalities. Rheumatology (Oxford). 2017;56(6):9349. https://doi.org/10.1093/rheumatology/kew506 PMid:28160488

36. Kim HJ, Kim MJ, Lee CK, Hong YH. Effects of methotrexate on carotid intima-media thickness in patients with rheumatoid arthritis. J Korean Med Sci. 2015;30(11):1589-96. https://doi. org/10.3346/jkms.2015.30.11.1589

PMid:26539002 